\title{
Pengajaran Remedial Untuk Mencapai Ketuntasan Hasil Belajar Siswa Pada Materi Pokok Garis Singgung Lingkaran
}

\author{
Sukinah \\ (E-mail: sukinahiskan@gmail.com)
}

\begin{abstract}
Abstrak
Sekolah yang menggunakan Kurikulum Berbasis Kompetensi, dalam penentuan kelulusan memperhatikan tiga aspek yaitu kognitif, psikomotor, dan afektif. Sedangkan untuk masing-masing aspek mempunyai Standar Ketuntasan Minimum (SKM).Terhadap siswa yang belum mencapai Standar Ketuntasan Minimum (SKM) tersebut perlu diberikan "bantuan" agar mencapai tujuan pembelajaran atau indikator yang telah ditetapkan. "Bantuan" yang diberikan berupa pengajaran remedial, dimana pengajaran remedial ini menjadi ciri khas dari penggunaan Kurikulum Berbasis Kompetensi (KBK). Dalam penelitian ini bentuk pengajaran remedial yang digunakan adalah mengajarkan kembali (re-teaching) untuk materi yang belum dicapai ketuntasannya oleh siswa. Pengajaran remedial bisa diterapkan pada semua materi pokok pelajaran matematika. Namun pada penelitian ini materi pokok yang digunakan adalah Garis Singgung Lingkaran. Hal tersebut didasarkan pada pengamatan yang telah dilakukan guru (pengajar) matematika selama mengajar di kelas VIII, bahwa pada materi pokok tersebut sering terdapat siswa yang tidak tuntas belajar. Tujuan dari penelitian ini adalah untuk mengatasi siswa yang tidak tuntas belajar, pengelolaan pembelajaran, respon siswa terhadap pembelajaran remedial. Subyek penelitian ini adalah siswa kelas VIIIF semester 2 SMP Negeri 33 Surabaya. Data yang diperoleh dengan tehnik observasi dan tehnik tes lalu dianalisis dengan menggunakan tehnik analisis data secara diskriptif.Hasil analisis menunjukkan bahwa pengajaran remedial dapat mengatasi siswa yang tidak tuntas belajar guna mencapai ketuntasan belajar siswa pada materi pokok garis singgung lingkaran dikelas VIII-F SMP Negeri 33 Surabaya.Guru dalam mengelola pembelajaran pada materi pokok Garis Singgung Lingkaran termasuk dalam kategori baik karena nilai yang diperoleh adalah 3,17 . Tanggapan siswa dengan diadakan pengajaran remedial pada materi pokok Garis Singgung Lingkaran adalah positif karena berdasarkan hasil angket yang diperoleh bahwa persentase tiap-tiap butir mencapai $\geq 65 \%$.
\end{abstract}

Kata Kunci: Remedial, aktifitas, hasil belajar

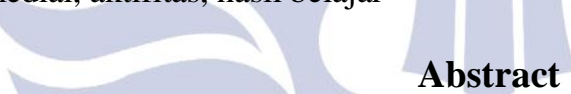

Schools using competency-based curriculum, in determining the graduation attention to three aspects: the cognitive, psychomotor, and affective. As for each aspect have Complete Standard Minimum (SKM) .Terhadap students who have not reached the Minimum Complete Standard (SKM) should be given "assistance" in order to achieve the learning objectives or indicators that have been set. "Help" is given in the form of remedial teaching, remedial teaching where this is characteristic of the use of competencybased curriculum (KBK). In this study used form of remedial teaching is to teach again (re-teaching) for material that has not been achieved ketuntasannya by students. Remedial teaching can be applied to any subject matter of math. But in this study the principal material used is Tangent Circle. It is based on the observations that have been made teachers (teaching) mathematics for teaching in class VIII, that the subject matter is often some students who do not pass the study. The purpose of this study is to address students who do not pass the study, learning management, students' response to remedial learning. The subjects of this study were students of class VIII-F semesters 2 SMP Negeri 33 Surabaya. Data obtained by observation technique and engineering tests are then analyzed using data analysis techniques are diskriptif.Hasil analysis showed that the remedial teaching can overcome students who do not pass the study in order to achieve mastery learning students in the subject matter circle tangent-F in class VIII SMP Negeri 33 Surabaya.Guru manage learning in the subject matter Tangent Circles included in either category because the value obtained was 3.17. Student responses organized remedial teaching in the subject matter Circle Tangent is positive because it is based on results of a questionnaire showed that the percentage of each point reached $\geq 65 \%$.

Keywords: remedial, activities , learning outcomes 


\section{PENDAHULUAN}

Salah satu upaya pemerintah untuk mencapai keunggulan masyarakat dalam penguasaan ilmu dan teknologi adalah dengan menggunakan Kurikulum Berbasis Kompetensi (KBK). KBK adalah suatu konsep kurikulum yang menekankan pada pengembangan kemampuan melakukan (kompetensi) tugas-tugas dengan standar performansi tertentu, sehingga hasilnya dapat dirasakan oleh peserta didik, berupa penguasaan terhadap seperangkat kompetensi tertentu. Dengan demikian, implementasi kurikulum dapat menumbuhkan tangung jawab, dan peserta didik untuk belajar menilai dan mempengaruhi kebijakan umum (public policy), serta memberanikan diri berperanserta dalam berbagai kegiatan, baik di sekolah maupun di masyarakat. (Mulyasa, 2002: 27)

Pada sekolah yang menggunakan Kurikulum Berbasis Kompetensi, dalam penentuan kelulusan memperhatikan tiga aspek yaitu kognitif, psikomotor, dan afektif. Sedangkan untuk masing-masing aspek mempunyai Standar Ketuntasan Minimum (SKM). Terhadap siswa yang belum mencapai Standar Ketuntasan Minimum (SKM) tersebut perlu diberikan "bantuan" agar mencapai tujuan pembelajaran atau indikator yang telah ditetapkan. "Bantuan" yang diberikan berupa pengajaran remedial, dimana pengajaran remedial ini menjadi ciri khas dari penggunaan Kurikulum Berbasis Kompetensi (KBK).

Remedial yang diterapkan di beberapa sekolah itu merupakan "ujian ulang" yaitu pemberian ujian bagi siswa yang belum tuntas belajar tanpa diberikan penjelasan materi ulang serta tingkat kesulitan soal tes yang diberikan sama dengan tingkat kesulitan soal tes sebelumnya, padahal yang dimaksud pengajaran remedial bukan ujian ulang tersebut. Menurut Warji (1987:42), ada beberapa bentuk Pengajaran Remidial yang dapat dilakukan, di antaranya adalah :Re-teaching, yaitu pengajaran remedial yang dilaksanakan dengan mengajarkan kembali bahan yang sama kepada para siswa yang memerlukan bantuan dengan cara penyajian yang berbeda.Menyuruh siswa mempelajari bahan yang sama dari buku pelajaran, buku paket atau sumber-sumber bacaan yang lain.Memberikan pekerjaan rumah yang harus dikerjakan oleh siswa.Bimbingan yang diberikan secara individu maupun kelompok kecil oleh guru atau pembimbing (siswa yang telah tuntas dan dapat dipercaya untuk menerangkan atau membantu temannya yang belum tuntas).

Dalam penelitian ini bentuk pengajaran remedial yang digunakan adalah mengajarkan kembali (re-teaching) untuk materi yang belum dicapai ketuntasannya oleh siswa.
Pengajaran remedial bisa diterapkan pada semua materi pokok pelajaran matematika. Namun pada penelitian ini materi pokok yang digunakan adalah Garis Singgung Lingkaran. Hal tersebut didasarkan pada pengamatan yang telah dilakukan guru (pengajar) matematika selama mengajar di kelas VIII, bahwa pada materi pokok tersebut sering terdapat siswa yang tidak tuntas belajar. Berdasarkan hal tersebut di atas, akhirnya penulis wujudkan dalam bentuk penelitian dengan judul "Pengajaran Remedial Untuk Mencapai Ketuntasan Belajar Siswa Pada Materi Pokok Garis Singgung Lingkaran Di Kelas VIII-F SMP Negeri 33 Surabaya".

Berdasarkan latar belakang tujuan penelitian ini adalah untuk mendiskripsikan hasil belajar siswa,pengelolaan pembelajarandan ketuntasan hasil belajar siswa setelah mengikuti pengajaran remedial di kelas VIII-F SMP Negeri 33 Surabaya, diharapakan dapat sebagai masukan bagi guru Matematika tentang pengajaran remedial yang berguna untuk mencapai ketuntasan belajar siswa pada materi pokok Garis singgung lingkaran di kelas VIII-F SMP Negeri 33 Surabaya, menambah pengetahuan tentang pelaksanaan pengajaran remedial sebagai upaya membantu siswa yang mengalami kesulitan belajar, memberikan masukan tentang pengajaran yang menekankan pada prestasi atau pencapaian seluruh siswa terhadap indicator yang telah ditetapkan.

Jenis penelitian yang dilakukan termasuk penelitian deskriptif. Penelitian deskriptif adalah penelitian yang diarahkan untuk memberikan gejala-gejala atau kejadian secara sistematis dan akurat mengenai sifat-sifat populasi atau daerah tertentu. (Yatin Riyanto, 2001: 23). Pengajaran remedial adalah suatu program yang membantu siswa lamban, kurang mengerti, menemui kesulitan belajar maupun yang gagal dalam mencapai tujuan pembelajaran. Pada penelitian ini pengajaran remedial yang diberikan adalah dengan mengajarkan kembali ( re-teaching) materi yang belum dicapai ketuntasannya oleh siswa. Ketuntasan Belajar Siswa adalah pencapaian tingkat penguasaan materi terhadap materi pelajaran yang telah diajarkan. Seorang siswa dikatakan mencapai ketuntasan belajar siswa secara individu apabila telah mencapai skor $\geq 65 \%$ dari skor maksimum (sesuai kesepakatan dari sekolah).Karena terbatasnya kemampuan penulis dan demi validnya simpulan yangdiambil, maka dalam penelitian ini diasumsikan bahwa: Soal tes valid karena disusun sesuai dengan kisi-kisi dan telah dikonsultasikan dengan dosen pembimbing dan guru mitra matematika yang bersangkutan.Angket diisi siswa secara jujur dan bersifat terbuka (disertai alasan) karena siswa dalam mengisi angket respon sesuai dengan pendapatnya tanpa dipengaruhi oleh orang lain serta sebelum pengisian 
angket ditekankan bahwa angket tersebut harus diisi sejujurnya dan tidak mempengaruhi skor matematika yang diperoleh. Penelitian ini hanya dilakukan pada siswa SMP Negeri 33 Surabaya kelas VIII-F semester 2 tahun pelajaran 2005 - 2006.

\section{METODE}

Penelitian ini termasuk penelitian deskriptif. Prosedur penelitian adalah sebagai berikut:

\begin{tabular}{|l|l|l|l|} 
Pengajaran Biasa & $\mathrm{X}_{1}$ & Pengajaran Remedial & $\mathrm{X}_{2}$ \\
\hline
\end{tabular}

\section{Keterangan:}

$\mathrm{X}_{1}=$ tes sebelum pengajaran remedial.

$\mathrm{X}_{2}=$ tes sesudah pengajaran remedial (bagi siswa yang

belum mencapai ketuntasan belajar).

Penelitian ini dilaksanakan dalam 4 kali pertemuan yang terdiri dari 2 kali pengajaran biasa dan 2 kali pengajaran remedial. Prosedur penelitian adalah sebagai berikut:

\section{Pengajaran Biasa}

\section{Perencanaan}

a. Mempersiapkan perangkat pembelajaran, meliputi: rencana pembelajaran dengan materi pokok Garis Singgung Lingkaran, dan lembar kerja siswa (LKS)

b. Mempersiapkan instrumen penelitian, meliputi: Lembar tes formatif, dan lembar observasi.

2. Pelaksanaan

a. Melaksanakan rencana pembelajaran.

b. Mengadakan evaluasi.

\section{Pengajaran Remedial}

1. Perencanaan

a. Mempersiapkan perangkat pembelajaran remedial, meliputi: rencana pembelajaran remedial dengan materi pokok Garis Singgung Lingkaran, dan lembar kerja siswa (LKS).

b. Mempersiapkan instrumen penelitian, meliputi: Lembar tes formatif, dan lembar observasi.

2. Pelaksanaan

a. Melaksanakan rencana pembelajaran remedial

b. Mengadakan evaluasi.

\section{HASIL DAN PEMBAHASAN}

\section{PENGAJARAN BIASA 1}

Pada hari Sabtu tanggal 6 Mei 2006 diadakan pembelajaran matematika dengan materi pokok Garis Singgung Lingkaran di kelas VIII-F SMP Negeri 33 Surabaya. Indikator pembelajaran pada pertemuan ini adalah melukis garis singgung persekutuan dalam dua lingkaran; menghitung panjang ruas garis singgung persekutuan dalam dua lingkaran. Alokasi waktu untuk pertemuan ini adalah 2 x 40 menit, yaitu 1 x 40 menit untuk penjelasan materi dan latihan terbimbing dan $1 \mathrm{x}$ 40 menit untuk pelaksanaan evaluasi 1 .

Berdasarkan hasil evaluasi 1, diperoleh daftar skor sebagai berikut:

Tabel 4. 2

Daftar Skor Evaluasi 1

\begin{tabular}{|c|c|c|c|c|c|c|c|c|c|}
\hline \multirow{2}{*}{$\begin{array}{c}\text { No. } \\
\text { Absen }\end{array}$} & \multirow{2}{*}{ Skor } & \multirow{2}{*}{$\begin{array}{c}\% \\
\text { Ketuntasan } \\
\text { Individu }\end{array}$} & \multicolumn{2}{|c|}{ Ketuntasan } & \multirow{2}{*}{$\begin{array}{c}\text { No. } \\
\text { Absen }\end{array}$} & \multirow{2}{*}{ Skor } & \multirow{2}{*}{$\begin{array}{c}\% \\
\text { Ketuntasan } \\
\text { Individu }\end{array}$} & \multicolumn{2}{|c|}{ Ketuntasan } \\
\hline & & & Ya & Tidak & & & & Ya & Tidak \\
\hline 1 & 92.5 & 92.5 & $\sqrt{ }$ & - & 21 & 97.5 & 97.5 & $\sqrt{ }$ & - \\
\hline 2 & 87.5 & 87.5 & $\sqrt{ }$ & - & 22 & 70 & 60 & - & $\sqrt{ }$ \\
\hline 3 & 77.5 & 77.5 & $\sqrt{ }$ & - & 23 & 97.5 & 97.5 & $\sqrt{ }$ & - \\
\hline 4 & 90 & 90 & $\sqrt{ }$ & - & 24 & 92.5 & 92.5 & $\sqrt{ }$ & - \\
\hline 5 & - & 0 & - & $\sqrt{ }$ & 25 & 95 & 95 & $\sqrt{ }$ & - \\
\hline 6 & 80 & 80 & $\sqrt{ }$ & - & 26 & 72.5 & 62.5 & - & $\sqrt{ }$ \\
\hline 7 & 97.5 & 97.5 & $\sqrt{ }$ & - & 27 & 100 & 100 & $\sqrt{ }$ & - \\
\hline 8 & 90 & 90 & $\sqrt{ }$ & - & 28 & 97.5 & 97.5 & $\sqrt{ }$ & - \\
\hline 9 & - & 0 & - & $\sqrt{ }$ & 29 & 92.5 & 92.5 & $\sqrt{ }$ & - \\
\hline 10 & 97.5 & 97.5 & $\sqrt{ }$ & - & 30 & 92.5 & 92.5 & $\sqrt{ }$ & - \\
\hline 11 & - & 0 & - & $\sqrt{ }$ & 31 & - & 0 & - & $\sqrt{ }$ \\
\hline 12 & 52.5 & 52.5 & - & $\sqrt{ }$ & 32 & 97.5 & 97.5 & $\sqrt{ }$ & - \\
\hline 13 & 62.5 & 62.5 & - & $\sqrt{ }$ & 33 & 97.5 & 97.5 & $\sqrt{ }$ & - \\
\hline 14 & 92.5 & 92.5 & $\sqrt{ }$ & - & 34 & 92.5 & 92.5 & $\sqrt{ }$ & - \\
\hline 15 & 92.5 & 92.5 & $\sqrt{ }$ & - & 35 & 80 & 80 & $\sqrt{ }$ & - \\
\hline 16 & 97.5 & 97.5 & $\sqrt{ }$ & - & 36 & 100 & 100 & $\sqrt{ }$ & - \\
\hline 17 & 97.5 & 97.5 & $\sqrt{ }$ & - & 37 & 62.5 & 62.5 & - & $\sqrt{ }$ \\
\hline 18 & 80 & 80 & $\sqrt{ }$ & - & 38 & 97.5 & 97.5 & $\sqrt{ }$ & - \\
\hline 19 & - & 0 & - & $\sqrt{ }$ & 39 & 95 & 95 & $\sqrt{ }$ & - \\
\hline 20 & 97.5 & 97.5 & $\sqrt{ }$ & - & 40 & 87.5 & 87.5 & $\sqrt{ }$ & - \\
\hline
\end{tabular}

Dari table 4.2 dapat dilihat bahwa siswa yang mencapai ketuntasan belajar adalah 30 siswa dan yang belum mencapai ketuntasan belajar individu sebanyak 10 siswa. Siswa dianggap tuntas jika \% ketuntasan individu yang diperoleh $\geq 65 \%$. Siswa yang belum mencapai ketuntasn belajar individu pada pelaksanaan evaluasi 1 akan mengikuti pengajaran remedial 1 .

\section{PENGAJARAN REMEDIAL 1}

Berdasarkan hasil evaluasi 1 terdapat 10 siswa yang belum mencapai ketuntasan belajar individu dari 40 siswa di kelas VIII-F. Oleh karena itu, terhadap siswa tersebut diberikan pengajaran remedial yang dilaksanakan pada hari Senin tanggal 8 Mei 2006. Alokasi waktu untuk pengajaran remedial ini adalah $2 \mathrm{x}$ 40 menit, yaitu 1 x 40 menit untuk penjelasan materi dan 1 x 40 menit untuk pelaksanaan evaluasi remedial 3 . Materi pokok pada pengajaran remedial ini adalah Garis Singgung Lingkaran dengan indikator pembelajaran 
adalah melukis garis singgung persekutuan dalam dua lingkaran; menghitung panjang ruas garis singgung persekutuan dalam dua lingkaran.

Berdasarkan hasil evaluasi remedial 1, diperoleh daftar skor sebagai berikut:

Tabel 4.3

Daftar Skor Siswa Sebelum dan Sesudah Pengajaran Remedial 1

\begin{tabular}{|c|c|c|c|c|c|c|c|}
\hline \multirow{2}{*}{ No } & \multirow{2}{*}{ No Absen } & \multicolumn{2}{|c|}{ Skor } & \multicolumn{2}{c|}{$\begin{array}{c}\text { Ketuntasan Belajar } \\
\text { Individu }\end{array}$} & \multicolumn{2}{c|}{ Ketuntasan } \\
\cline { 3 - 9 } & & $\begin{array}{c}\text { Sebelum P. } \\
\text { Remedial }\end{array}$ & $\begin{array}{c}\text { Sesudah P. } \\
\text { Remedial }\end{array}$ & $\begin{array}{c}\text { Sebelum P. } \\
\text { Remedial }\end{array}$ & $\begin{array}{c}\text { Sesudah P. } \\
\text { Remedial }\end{array}$ & Ya & Tidak \\
\hline 1 & 5 & - & - & 0 & 0 & - & $\sqrt{ }$ \\
\hline 2 & 9 & - & 80 & 0 & 80 & $\sqrt{ }$ & - \\
\hline 3 & 11 & - & - & 0 & 0 & - & $\sqrt{ }$ \\
\hline 4 & 12 & 52.5 & 75 & 52.5 & 75 & $\sqrt{ }$ & - \\
\hline 5 & 13 & 62.5 & 85 & 62.5 & 85 & $\sqrt{ }$ & - \\
\hline 6 & 19 & - & 75 & 0 & 75 & $\sqrt{ }$ & - \\
\hline 7 & 22 & 70 & 90 & 70 & 90 & $\sqrt{ }$ & - \\
\hline 8 & 26 & 72.5 & 90 & 72.5 & 90 & $\sqrt{ }$ & - \\
\hline 9 & 31 & - & 75 & 0 & 75 & $\sqrt{ }$ & - \\
\hline 10 & 37 & 62.5 & 82.5 & 62.5 & 82.5 & $\sqrt{ }$ & - \\
\hline
\end{tabular}

Dari table 4.3 dapat dilihat bahwa ada peningkatan skor pada siswa yang mengikuti pengajaran remedial. Ada 2 siswa yang tidak tuntas belajar dikarenakan siswa tersebut tidak mengikuti pelaksanaan evaluasi 1 dan evaluasi remedial 1 .

\section{PENGAJARAN BIASA 2}

Pada hari Selasa tanggal 9 Mei 2006 diadakan pembelajaran matematika dengan materi pokok Garis Singgung Lingkaran di kelas VIII-F SMP Negeri 33 Surabaya. Indikator pembelajaran pada pertemuan ini adalah melukis garis singgung persekutuan luar dua lingkaran; menghitung panjang garis singgung persekutuan luar; menghitung panjang sabuk lilitan minimal yang menghubungkan dua lingkaran dengan rumus. Alokasi waktu untuk pertemuan ini adalah 2 x 40 menit, yaitu 1 x 40 menit untuk penjelasan materi dan latihan terbimbing dan 1 × 45 menit untuk pelaksanaan evaluasi 2.

Berdasarkan hasil evaluasi 2, diperoleh daftar skor sebagai berikut:

Tabel 4. 4

Daftar Skor Evaluasi 2

\begin{tabular}{|c|c|c|c|c|c|c|c|c|c|}
\hline \multirow{2}{*}{$\begin{array}{c}\text { No. } \\
\text { Absen }\end{array}$} & \multirow{2}{*}{ Skor } & \multirow{2}{*}{$\begin{array}{c}\% \\
\text { Ketuntasan } \\
\text { Individu }\end{array}$} & \multicolumn{2}{|c|}{ Ketuntasan } & \multirow{2}{*}{$\begin{array}{c}\text { No. } \\
\text { Absen }\end{array}$} & \multirow{2}{*}{ Skor } & \multirow{2}{*}{$\begin{array}{c}\% \\
\text { Ketuntasan } \\
\text { Individu }\end{array}$} & \multicolumn{2}{|c|}{ Ketuntasan } \\
\hline & & & Ya & Tidak & & & & $\mathrm{Ya}$ & Tidak \\
\hline 1 & $\begin{array}{c}72 . \\
5\end{array}$ & 62.5 & - & $\sqrt{ }$ & 21 & 97.5 & 97.5 & $\sqrt{ }$ & - \\
\hline 2 & 95 & 95 & $\sqrt{ }$ & - & 22 & 90 & 90 & $\sqrt{ }$ & - \\
\hline 3 & - & 0 & - & $\sqrt{ }$ & 23 & 97.5 & 97.5 & $\sqrt{ }$ & - \\
\hline
\end{tabular}

\begin{tabular}{|c|c|c|c|c|c|c|c|c|c|}
\hline \multirow{2}{*}{$\begin{array}{l}\text { No. } \\
\text { Absen }\end{array}$} & \multirow{2}{*}{ Skor } & \multirow{2}{*}{$\begin{array}{c}\% \\
\text { Ketuntasan } \\
\text { Individu }\end{array}$} & \multicolumn{2}{|c|}{ Ketuntasan } & \multirow{2}{*}{$\begin{array}{l}\text { No. } \\
\text { Absen }\end{array}$} & \multirow{2}{*}{ Skor } & \multirow{2}{*}{$\begin{array}{c}\% \\
\text { Ketuntasan } \\
\text { Individu }\end{array}$} & \multicolumn{2}{|c|}{ Ketuntasan } \\
\hline & & & Ya & Tidak & & & & $\mathrm{Ya}$ & Tidak \\
\hline 4 & $\begin{array}{c}92 . \\
5\end{array}$ & 92.5 & $\sqrt{ }$ & - & 24 & 92.5 & 92.5 & $\sqrt{ }$ & - \\
\hline 5 & - & 0 & - & $\sqrt{ }$ & 25 & 82.5 & 82.5 & $\sqrt{ }$ & - \\
\hline 6 & $\begin{array}{c}82 . \\
5\end{array}$ & 82.5 & $\sqrt{ }$ & - & 26 & 92.5 & 92.5 & $\sqrt{ }$ & - \\
\hline 7 & 95 & 95 & $\sqrt{ }$ & - & 27 & 97.5 & 97.5 & $\sqrt{ }$ & - \\
\hline 8 & $\begin{array}{c}92 . \\
5\end{array}$ & 92.5 & $\sqrt{ }$ & - & 28 & - & 0 & - & $\sqrt{ }$ \\
\hline 9 & $\begin{array}{c}87 . \\
5\end{array}$ & 87.5 & $\sqrt{ }$ & - & 29 & 55 & 55 & - & $\sqrt{ }$ \\
\hline 10 & $\begin{array}{c}97 . \\
5\end{array}$ & 97.5 & $\sqrt{ }$ & - & 30 & 97.5 & 97.5 & $\sqrt{ }$ & - \\
\hline 11 & - & 0 & - & $\sqrt{ }$ & 31 & 85 & 85 & $\sqrt{ }$ & - \\
\hline 12 & $\begin{array}{c}72 . \\
5\end{array}$ & 62.5 & - & $\sqrt{ }$ & 32 & 92.5 & 92.5 & $\sqrt{ }$ & - \\
\hline 13 & $\begin{array}{c}92 . \\
5 \\
\end{array}$ & 92.5 & $\sqrt{ }$ & - & 33 & 97.5 & 97.5 & $\sqrt{ }$ & - \\
\hline 14 & $\begin{array}{c}97 . \\
5\end{array}$ & 97.5 & $\sqrt{ }$ & - & 34 & - & 0 & - & $\sqrt{ }$ \\
\hline 15 & $\begin{array}{c}72 . \\
5\end{array}$ & 62.5 & - & $\sqrt{ }$ & 35 & 87.5 & 87.5 & $\sqrt{ }$ & - \\
\hline 16 & $\begin{array}{c}97 . \\
5\end{array}$ & 97.5 & $\sqrt{ }$ & - & 36 & 97.5 & 97.5 & $\sqrt{ }$ & - \\
\hline 17 & $\begin{array}{c}72 . \\
5\end{array}$ & 62.5 & - & $\sqrt{ }$ & 37 & 92.5 & 92.5 & $\sqrt{ }$ & - \\
\hline 18 & 95 & 95 & $\sqrt{ }$ & - & 38 & 97.5 & 97.5 & $\sqrt{ }$ & - \\
\hline 19 & 95 & 95 & $\sqrt{ }$ & - & 39 & 80 & 80 & $\sqrt{ }$ & - \\
\hline 20 & $\begin{array}{c}92 . \\
5\end{array}$ & 92.5 & $\sqrt{ }$ & - & 40 & 85 & 85 & $\sqrt{ }$ & - \\
\hline
\end{tabular}

Dari table 4. 4 dapat dilihat bahwa siswa yang mencapai ketuntasan belajar adalah 30 siswa dan yang belum mencapai ketuntasan belajar individu sebanyak 10 siswa. Siswa dianggap tuntas jika \% ketuntasan individu yang diperoleh $\geq 65 \%$. Siswa yang belum mencapai ketuntasn belajar individu pada pelaksanaan evaluasi 2 akan mengikuti pengajaran remedial 2 .

\section{PENGAJARAN REMEDIAL 2}

Berdasarkan hasil evaluasi 4 terdapat 10 siswa yang belum mencapai ketuntasan belajar individu dari 40 siswa di kelas VIII-F. Oleh karena itu, terhadap siswa tersebut diberikan pengajaran remedial yang dilaksanakan pada hari Sabtu tanggal 13 Mei 2006. Alokasi waktu untuk pengajaran remedial ini adalah $2 \mathrm{x}$ 40 menit, yaitu $1 \times 40$ menit untuk penjelasan materi dan 1 x 40 menit untuk pelaksanaan evaluasi remedial 4 . Materi pokok pada pengajaran remedial ini adalah Garis Singgung Lingkaran dengan indikator pembelajaran adalah melukis garis singgung persekutuan luar dua lingkaran; menghitung panjang garis singgung persekutuan luar; menghitung panjang sabuk lilitan minimal yang menghubungkan dua lingkaran dengan rumus.

Berdasarkan hasil evaluasi remedial 2, diperoleh daftar skor sebagai berikut: 
Tabel 4.5

Daftar Skor Siswa Sebelum dan Sesudah Pengajaran Remedial 2

\begin{tabular}{|c|c|c|c|c|c|c|c|}
\hline \multirow{2}{*}{ No } & \multirow{2}{*}{$\begin{array}{c}\text { No } \\
\text { Absen }\end{array}$} & \multicolumn{3}{|c|}{ Skor } & \multicolumn{2}{c|}{$\begin{array}{c}\text { \% Ketuntasan } \\
\text { Belajar Individu }\end{array}$} & \multicolumn{2}{c|}{$\begin{array}{c}\text { Ketuntasa } \\
n\end{array}$} \\
\cline { 3 - 10 } & & $\begin{array}{c}\text { Sebelum P. } \\
\text { Remedial }\end{array}$ & $\begin{array}{c}\text { Sesudah P. } \\
\text { Remedial }\end{array}$ & $\begin{array}{c}\text { Sebelum } \\
\text { P. } \\
\text { Remedial }\end{array}$ & $\begin{array}{c}\text { Sesudah P. } \\
\text { Remedial }\end{array}$ & Ya & Tidak \\
\hline 1 & 1 & 72.5 & 85 & 72.5 & 85 & $\sqrt{ }$ & - \\
\hline 2 & 3 & - & 80 & 0 & 80 & $\sqrt{ }$ & - \\
\hline 3 & 5 & - & - & 0 & 0 & - & $\sqrt{ }$ \\
\hline 4 & 11 & - & - & 0 & 0 & - & $\sqrt{ }$ \\
\hline 5 & 12 & 72.5 & 75 & 72.5 & 75 & $\sqrt{ }$ & - \\
\hline 6 & 15 & 72.5 & 80 & 72.5 & 80 & $\sqrt{ }$ & - \\
\hline 7 & 17 & 72.5 & 80 & 72.5 & 80 & $\sqrt{ }$ & - \\
\hline 8 & 28 & - & - & 0 & 0 & - & $\sqrt{ }$ \\
\hline 9 & 29 & 55 & 85 & 55 & 85 & $\sqrt{ }$ & - \\
\hline 10 & 34 & - & 75 & 0 & 75 & $\sqrt{ }$ & - \\
\hline & & & & & & & \\
\hline
\end{tabular}

Dari tabel 4.5 dapat dilihat bahwa ada peningkatan skor pada siswa yang mengikuti pengajaran remedial. Ada 2 siswa yang tidak tuntas belajar dikarenakan siswa tersebut tidak mengikuti pelaksanaan evaluasi 2 dan evaluasi remedial 2 .

\section{ANALISIS DATA HASIL OBSERVASI PENGELOLAAN PEMBELAJARAN}

Analisis data hasil observasi pengelolaan pembelajaran adalah sebagai berikut:

Tabel 4. 6

Hasil Observasi Pengelolaan Pembelajaran

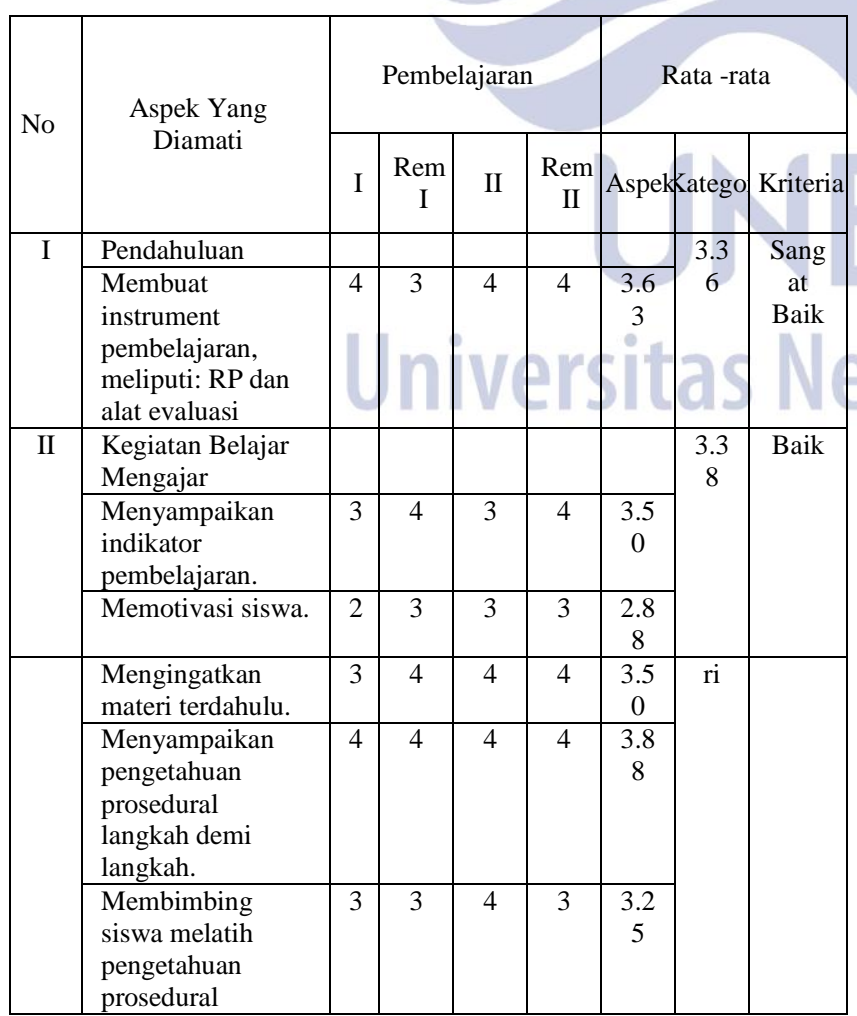

\begin{tabular}{|c|c|c|c|c|c|c|c|c|}
\hline \multirow{5}{*}{ No } & \multirow{2}{*}{$\begin{array}{c}\text { Aspek Yang } \\
\text { Diamati }\end{array}$} & \multicolumn{4}{|c|}{ Pembelajaran } & \multicolumn{3}{|c|}{ Rata -rata } \\
\hline & & I & $\begin{array}{c}\text { Rem } \\
\text { I }\end{array}$ & II & $\begin{array}{c}\text { Rem } \\
\text { II }\end{array}$ & Aspek & Katego & Kriteria \\
\hline & $\begin{array}{l}\text { langkah demi } \\
\text { langkah. }\end{array}$ & & & & & & & \\
\hline & $\begin{array}{l}\text { Mengecek } \\
\text { pemahaman siswa } \\
\text { dan memberi } \\
\text { umpan balik. }\end{array}$ & 2 & 3 & 3 & 4 & $\begin{array}{c}3.0 \\
0\end{array}$ & & \\
\hline & $\begin{array}{l}\text { Memberikan } \\
\text { latihan lanjutan } \\
\text { dan penerapan. }\end{array}$ & 3 & 4 & 4 & 3 & $\begin{array}{c}3.6 \\
3\end{array}$ & & \\
\hline III & $\begin{array}{l}\text { Pengelolaan } \\
\text { Waktu }\end{array}$ & 3 & 2 & 3 & 2 & $\begin{array}{c}2.7 \\
5\end{array}$ & $\begin{array}{c}2.7 \\
5\end{array}$ & Baik \\
\hline \multirow[t]{3}{*}{ IV } & $\begin{array}{l}\text { Pengelolaan } \\
\text { Suasana }\end{array}$ & & & & & & \multirow[t]{3}{*}{$\begin{array}{c}2.9 \\
4\end{array}$} & \multirow[t]{3}{*}{ Baik } \\
\hline & Guru antusias & 3 & 3 & 3 & 3 & $\begin{array}{c}3.2 \\
5\end{array}$ & & \\
\hline & Siswa antusias & 3 & 2 & 2 & 3 & $\begin{array}{c}2.6 \\
3\end{array}$ & & \\
\hline & & & & & & & 3.17 & Baik \\
\hline
\end{tabular}

Keterangan:

I, II = pembelajaran biasa I, II

REM I, REM II = pembelajaran remedial I, II, Berdasarkan table 4. 6 dapat dilihat bahwa:

1. Pada tahap Pendahuluan mendapat nilai 3.63 yang berarti bahwa kemampuan guru pada tahap pendahuluan termasuk dalam kategori sangat baik

2. Pada tahap Kegiatan Belajar Mengajar mendapat nilai 3.38 yang berarti bahwa kemampuan guru baik pada tahap tersebut. Hal ini dikarenakan guru telah menyampaikan indikator, memotivasi siswa, mengingatkan materi terdahulu, menyampaikan pengetahuan, membimbing siswa, mengecek pemahaman siswa, dan memberikan latihan lanjutan. Memeriksa kembali hasil yang telah diperoleh berturut-turut bernilai $3.50 ; 2.88 ; 3.50 ; 3.88 ; 3.25$; 3.00; dan 3.63.

3. Pada tahap Pengelolaan Waktu mendapat nilai 2.75 hal ini berarti kemampuan guru termasuk dalam kategori baik. Hal tersebut dikarenakan guru telah memberikan alokasi waktu untuk melaksanakan tiap langkah dalam rencana pembelajaran sehingga waktu yang ada dapat digunakan seefektif mungkin.

4. Pada tahap Pengelolaan Suasana mendapat nilai 2.94 hal ini berarti kemampuan guru termasuk dalam kategori baik dikarenakan guru dan siswa antusias dalam mengikuti pembelajaran.

Berdasarkan Tabel 4. 6 dapat dilihat rata-rata hasil pengamatan terhadap kemampuan guru dalam mengelola pembelajaran mendapat nilai 3.17 , sesuai dengan Tingkat Kemampuan Guru (TKG) yang dikemukakan pada bab 
III, maka kemampuan guru dalam mengelola pembelajaran dikategorikan baik.

\section{B. ANALISIS DATA ANGKET RESPON SISWA}

Dari 40 siswa dikelas VIII F yang telah mengikuti pengajaran remedial, diberikan angket yang berisi 8 butir pertanyaan. Angket yang terkumpul dan telah diisi oleh siswa berjumlah 38, karena pada saat pengisian angket ada 2 siswa yang absen. Berdasarkan hasil pengisian angket dilakukan analisis terhadap angket dan diperoleh data sebagai berikut:

Tabel 4.7

Hasil angket siswa

\begin{tabular}{|c|c|c|c|c|c|}
\hline \multirow[t]{2}{*}{ No } & \multirow[t]{2}{*}{ Pertanyaan } & \multicolumn{2}{|c|}{$\begin{array}{c}\text { Siswa Yang } \\
\text { Menjawab }\end{array}$} & \multicolumn{2}{|c|}{$\begin{array}{l}\text { \% Siswa } \\
\text { Yang } \\
\text { Menjawab }\end{array}$} \\
\hline & & A & B & $\mathrm{A}$ & B \\
\hline 1 & $\begin{array}{l}\text { Pernahkah diadakan } \\
\text { pengajaran remedial di } \\
\text { sekolah Anda? }\end{array}$ & 38 & & 100 & 0 \\
\hline 2 & $\begin{array}{l}\text { Menurut Anda } \\
\text { perlukah diadakan } \\
\text { pengajaran }\end{array}$ & 36 & 2 & 94.7 & 5.3 \\
\hline & $\begin{array}{l}\text { remedial pada materi } \\
\text { pokok Garis Singgumg } \\
\text { Lingkaran? }\end{array}$ & & & & \\
\hline 3 & $\begin{array}{l}\text { Dengan diadakan } \\
\text { pengajaran remedial, } \\
\text { adakah manfaat yang } \\
\text { anda peroleh? }\end{array}$ & 38 & - & 100 & 0 \\
\hline 4 & $\begin{array}{l}\text { Apakah pemehaman } \\
\text { Anda semakin } \\
\text { bertambah dengan } \\
\text { diadakan pengajaran } \\
\text { remedial? }\end{array}$ & 38 & & 100 & 0 \\
\hline 5 & $\begin{array}{l}\text { Apakah pengajaran } \\
\text { remedial perlu } \\
\text { diadakan pada mata } \\
\text { pelejaran lain? }\end{array}$ & 34 & 4 & 89.5 & 10.5 \\
\hline 6 & $\begin{array}{l}\text { Bagaimana perasaan } \\
\text { Anda dengan diadakan } \\
\text { pengajaran remedial? }\end{array}$ & 38 & - & 100 & 0 \\
\hline 7 & $\begin{array}{l}\text { Bagaimana suasana } \\
\text { kelas Anda saat } \\
\text { pengajaran remedial } \\
\text { berlangsung? }\end{array}$ & 33 & 5 & 86.8 & 13.2 \\
\hline 8 & $\begin{array}{l}\text { Apakah dengan } \\
\text { pengajaran remedial } \\
\text { keinginan Anda untuk } \\
\text { belajar semakin } \\
\text { bertambah? }\end{array}$ & 37 & -1 & 97.4 & 2.6 \\
\hline
\end{tabular}

Dari table 4.11 dapat dilihat bahwa:

1. Untuk pertanyaan 1, semua siswa menjawab " A'. Hal ini menunjukkan bahwa di SMP Negeri 33 Surabaya pernah diadakan pengajaran remedial.

2. Untuk pertanyaan 2, siswa yang merasa perlu diadakan pengajaran remedial sebanyak 94,7\% (36 siswa)

3. Untuk pertanyaan 3 , semua siswa menjawab "A". Hal ini menunjukkan bahwa semua siswa memperoleh manfaat dengan diadakannya pengajaran remedial.

4. Untuk pertanyaan 4, semua siswa menjawab "A". Hal ini menunjukkan bahwa pemahaman siswa semakin bertambah dengan diadakannya pengajaran remedial.

5. Untuk pertanyaan 5, siwa yang merasa perlu diadakan pengajaran remedial pada mata pelajaran lain sebanyak $89,5 \%$ (34 siswa).

6. Untuk pertanyaan 6, semua siswa menjawab"A". Hal ini menunjukkan bahwa semua siswa senang dengan diadakan pengajaran remedial.

7. Untuk pertanyaan 7, siswa yang merasa bahwa suasana kelas aktif pada saat pengajaran remedial berlangsung sebanyak 86,8\% (33 siswa).

8. Untuk pertanyaan 8 , siswa yang merasa keinginan belajarnya semakin bertambah dengan diadakannya pengajaran remedial sebannyak $97,4 \%$ (37 siswa).

\section{PENUTUP}

\section{Simpulan}

Berdasarkan hasil analisis data dapat disimpulkan sebagai berikut:

1)Pengajaran remedial dapat mengatasi siswa yang tidak tuntas belajar guna mencapai ketuntasan belajar siswa pada materi pokok garis singgung lingkaran dikelas VIIIF SMP Negeri 33 Surabaya. 2) Guru dalam mengelola pembelajaran pada materi pokok Garis Singgung.

\section{Saran}

Lingkaran termasuk dalam kategori baik karena nilai yang diperoleh adalah 3,17.(3)Tanggapan siswa dengan diadakan pengajaran remedial pada materi pokok Garis Singgung Lingkaran adalah positif karena berdasarkan hasil angket yang diperoleh bahwa persentase tiap-tiap butir mencapai $\geq 65 \%$.(4)Pengajaran remedial dapat digunakan sebagai salah satu cara untuk membantu siswa mencapai ketuntasan belajar pada materi pokok Garis Singgung Lingkaran karena pada pengajaran remedial siswa yang belum tuntas belajar akan mendapatkan lagi materi yang sudah diajarkan.(5)Hendaknya dilakukan penelitian lanjutan tentang pengajaran remedial pada materi pokok lain sehingga ketuntasan belajar siswa pada indikator yang ditetapkan dapat dicapai.

\section{DAFTAR PUSTAKA}

Ahmadi dan Widodo. 1991. Psikologi Belajar. Jakarta: Rineka Cipta. 
Arikunto, Suharsimi. 2003. Dasar-Dasar Evaluasi pendidikan. Jakarta: Bumi Aksara.

Cholik dan Sugijono. 2005. Matematika Untuk SMP Kelas VIII. Jakarta: Erlangga.

Depdiknas. 2003. Kurikulum 2004 Standar Kompetensi Mata Pelajaran Matematika SMP dan MTs. Jakarta: Depdiknas.

Dirjen Pendidikan Dasar dan Menengah. 2004. Pedoman Umum Sistem Penilaian Sekolah Menengah Pertama (SMP). Jakarta: Diknas.

Hadi Prasetyo, Krisdianto. 2004. Pembelajaran Matematika Realistis Pokok Bahasan Transformasi di SLTP Negeri 2 Sukoharjo. Tesis yang tidak dipublikasikan. Surabaya: UNESA.

Mulyasa. 2002. Kurikulum Berbasis Kompetensi. Bandung: Rosda.

Prasetyo, Henry. 2000. Pengaruh Pemberian Tes formatif terhadap Prestasi Belajar Siswa pada Pokok Bahasan Lingkaran Semester IV di Kelas II SLTP Negeri 2 Parang Th. 2002/2003. Skripsi Yang Dipublikasikan. Surabaya: University Press.

Riyanto, Yatin. 2001. Metodologi Penelitian Pendidikan.Surabaya: SIC.

Subagyo, Ardi. 2004. Pembelajaran Kooperatif dengan Pendekatan Open-Zended pada Pokok Bahasan Garis-Garis Sejajar Untuk Siswa Kelas 2 SLTP Negeri II Palangkaraya. Tesis Yang Tidak Dipublikasi. Surabaya: UNESA.

Syah, Muhibbin. 1995. Psikologi Pendidikan. Bandung: Remaja Rosdakarya

Warji dan Ischak. 1987. Program Remedial dalam Proses Belajar Mengajar. Yogyakarta: Liberty.

W.S. Winkel. SJ. 1984. Psikologi Pendidikan dan Evaluasi Belajar. Jakarta: PN Balai Pustaka. 